\title{
MODAL SIMBOLIK KEKUASAAN DALAM NASKAH DRAMA BUNGA RUMAH MAKAN KARYA UTUY TATANG SONTANI (KAJIAN PIERRE BOURDIUE)
}

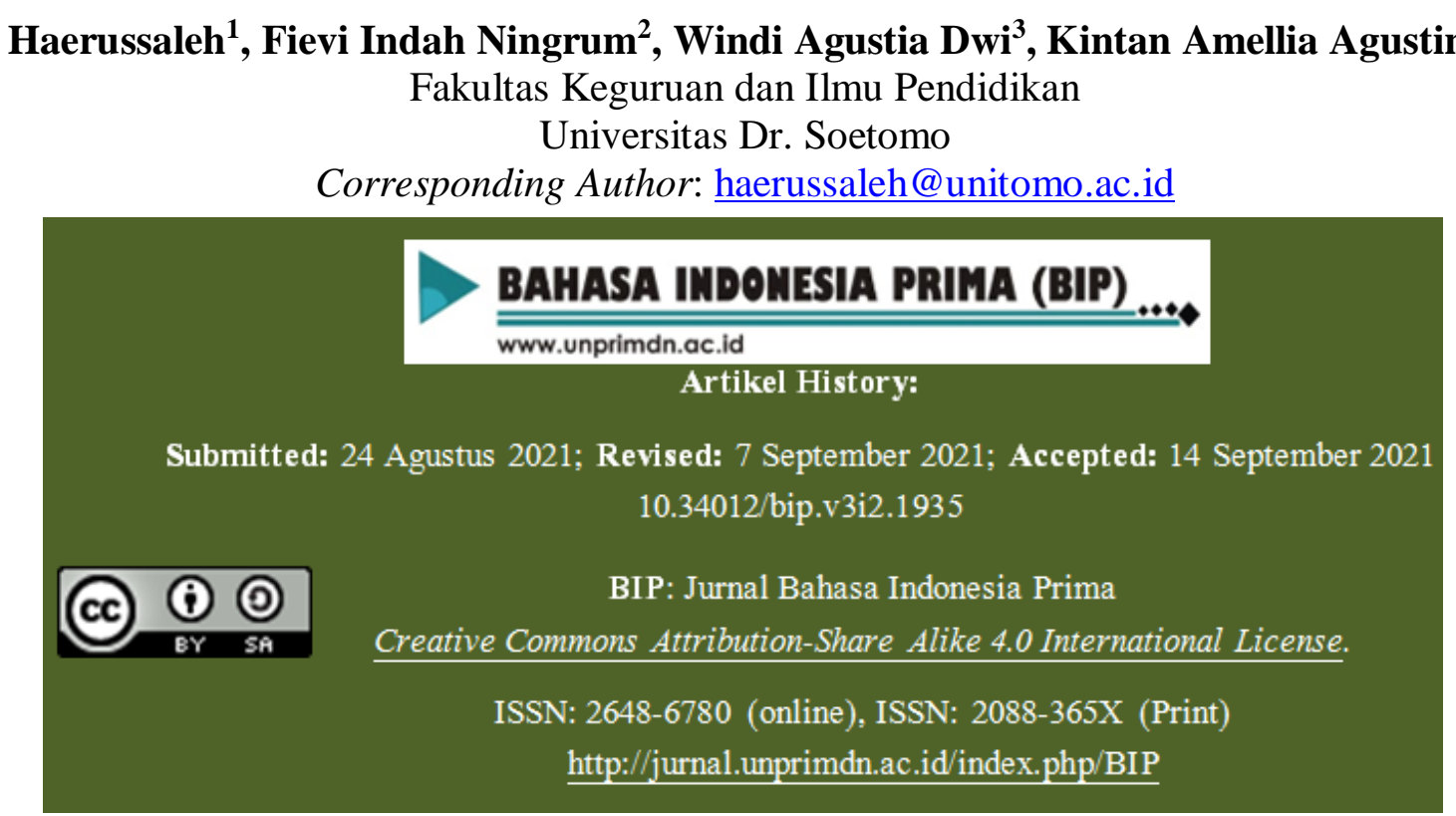

Abstrak-Modal simbolik kekuasaan yang ditemukan dalam naskah drama tersebut adalah (1) modal simbolik dalam ranah pekerjaan dengan simbol jabatan dan prestise atau citra. Modal simbolik dalam bentuk jabatan lebih sering digunakan oleh tokoh Sudarma sebagai pemilik rumah makan yang tentunya memiliki wewenang dan hak untuk memerintah. Sedangkan, modal simbolik dalam bentuk prestise atau citra juga digunakan oleh tokoh Sudarma untuk melanggengkan kekuasaannya. Prestise atau citra dalam hal ini berupa sesuatu yang dapat menghasilkan keuntungan atau ekonomi; (2) modal simbolik dalam ranah masyarakat yang ditemukan hanya status sosial, status sosial dalam masyarakat juga merupakan modal simbolik. Dalam naskah drama Bunga Rumah Makan status sosial digunakan oleh tokoh Sudarma, Karnaen, dan Usman untuk melanggengkan kekuasaannya.

Kata kunci: modal, simbolik, drama

Abstract-The symbolic capital of power found in the drama script is (1) symbolic capital in the realm of work with symbols of position and prestige or image. Symbolic capital in the form of positions is more often used by Sudarma figures as restaurant owners who of course have the authority and right to govern. Meanwhile, symbolic capital in the form of prestige or image is also used by Sudarma figures to perpetuate his power. Prestige or image in this case in the form of something that can generate profit or economy; (2) symbolic capital in the realm of society found only social status, social status in society is also symbolic capital. In the drama script Bunga Rumah Makan, social status is used by the characters Sudarma, Karnaen, and Usman to perpetuate their power.

Keywords: capital, symbolic, drama

\section{A. Pendahuluan}

Karya sastra merupakan hasil pengungkapan atau pemikiran mengenai suasana kejiwaan seorang pengarang yang berupa perasaan, ide, atau pengalaman berdasarkan realitas sosial budaya suatu 
masyarakat, sehingga dalam sebuah karya sastra erat hubungannya dengan interaksi antar manusia dan lingkungan. Karya sastra menyuguhkan peristiwa atau kejadian yang dialami oleh masyarakat. Hasil pengungkapan atau pemikiran tersebut kemudian diinterpretasikan melalui tulisan. Konflik atau permasalahan yang dituangkan dalam sebuah cerita didasarkan pada pengamatan atau pengalaman pengarang, sehingga isi cerita membuat pembaca seolah-olah ikut merasakan apa yang di alami dalam sebuah cerita. Karya sastra merupakan hasil imajinasi dan fiksi (Susanto, 2016:17).

Karya sastra dipersepsikan sebagai bentuk pengungkapan nyata dalam kehidupan yang disusun secara sistematis, dan menarik. Sebagai karya yang sifatnya imajinasi, karya sastra menjadi media pengungkapan curahan hati bagi pengarangnya yang dituangkan dalam bentuk tulisan yang dapat berupa puisi, cerpen, novel, maupun naskah drama. Karya sastra drama berbeda dengan puisi dan prosa. Dalam sebuah karya sastra, tokoh merupakan bagian penting. Tokoh dapat membangun dan menghidupkan sebuah karya sastra. Setiap tokoh memiliki watak yang berbeda-beda yang dapat dijadikan sebagai inspirasi bagi para pembacanya karena masing-masing tokoh membawakan sebuah pesan termasuk dalam drama.

Drama merupakan salah satu jenis karya sastra. Drama memiliki makna perbuatan, atau tindakan. Drama adalah tiruan dari kehidupan manusia yang dipentaskan di atas panggung. Namun sebelum dilakukan pementasan drama, naskah drama sangat penting untuk dipersiapkan terlebih dahulu karena naskah drama masih berbentuk sebuah karangan atau tulisan yang berupa perbuatan dan tindakan yang belum ditampilkan di atas panggung. Naskah drama adalah sebuah tiruan kehidupan manusia yang diproyeksikan dalam sebuah pentas. Melalui drama, penonton seolah melihat kejadian dalam masyarakat.

Utuy Tatang Sontani merupakan salah satu sastrawan angkatan 45, karya pertama yang ditulis berjudul Tambera (versi bahasa Sunda). Setelah itu, Utuy menerbitkan kumpulan cerita-cerita pendek diantaranya, Orang-Orang Sial (1951) diikuti oleh karya-karya lakonnya yang membuatnya menjadi terkenal, pementasan pertamannya berjudul Suling dan Bunga Rumah Makanp ada tahun 1948 yang ditulis seperti cerpen sebelumnya, dan menentang idealisme yang tidak realistis, Utuy Tatang Sontani juga dikenal sebagaipenulis yang humanis.

Naskah drama Bunga Rumah Makan ditulis oleh Utuy Tatang Sontani tepat dua tahun setelah Indonesia merdeka. Naskah drama Bunga Rumah Makan menceritakan tentang sosok Ani yang memiliki paras rupawan, Ia bekerja sebagai pelayan di Rumah Makan "Sambara" milik Sudarma. Keponakan dari Sudarma yang bernama Karnaen menaruh hati kepada sosok Ani namun Ani selalu menolak dan cintanya bertepuk sebelah tangan. Hal tersebut membuat Karnean melakukan berbagai cara untuk mencuri perhatian dari Ani. Namun, cinta Karnean tiba-tiba kandas karena Ani lebih memilih seorang kapten tentara yang bernama Suherman, tetapi karena sikapnya yang tidak baik Ani meninggalkan Suherman. Ani mendapatkan seorang pengganti yang bernama Iskandar. Iskandar adalah seorang gelandangan yang tidak memiliki pekerjaan, tetapi ia memiliki sifat 
kejujuran dan kebenaran di setiap tindakannya.

Aspek yang menarik dalam naskah drama Bunga Rumah Makan adalah meskipun mengisahkan tentang percintaan seorang gadis yang diperebutkan oleh lelaki, tetapi cerita dalam naskah drama ini juga menentang dan melakukan pembelaan terhadap tokoh yang mengalami eksploitasi secara stratifikasi sosial yang merupakan korban ketidakadilan oleh orang-orang kaya, sehingga hal tersebut yang menjadikan sebuah alasan naskah Bunga Rumah Makan dijadikan sebagai objek penelitian karena naskah drama Bunga Rumah Makan menceritakan tentang dominasi kekuasaan, sela ini tunaskah drama Bunga Rumah Makan juga belum pernah dikaji menggunakan modal simbolik kekuasaan dengan kajian Pierre Bourdieu.

\section{B. Metode Penelitian Pendekatan Penelitian}

Pendekatan yang digunakan dalam penelitian ini adalah pendekatan sosiologi sastra. Sosiologi merupakan sebuah ilmu pengetahuan yang mengkaji tentang aktivitas sosial manusia (Fananie, 2000:132). Sedangkan sastra adalah sebuah ungkapan perasaan atau ekspresi yang ditunjukkan oleh tiap individu atau kelompok dalam masyarakat yang kemudian dituangkan ke dalam sebuah karya seni. Hubungan antara sosiologi dengan sastra cukup melekat dalam kehidupan bermasyarakat sastra juga dapat muncul dengan sendirinya. Begitu juga sebaliknya, dalam dunia sastra, masyarakat menjadi objek utamanya.

\section{Data dan Sumber Data}

Data dalam penelitian ini berupa katakata, kalimat, penggalan kalimat, paragraf, maupun penggalan paragraf yang ada dalam naskah drama Bunga Rumah Makan karya Utuy Tatang Sontani. Data yang diteliti berkaitan dengan kajian modal simbolik kekuasaan dari Pierre Bourdieu yang akan menjawab rumusan masalah yang ada pada penelitian.Sumber data dalam penelitian ini berupa naskah drama Bunga Rumah Makan karya Utuy Tatang Sontani.

\section{Teknik Pengumpulan Data}

Teknik pengumpulan data dalam penelitian menggunakan teknik studi pustaka. Teknik studi pustaka merupakan teknik yang digunakan untuk menemukan segala sumber yang terkait dengan data penelitian (Faruk, 2012: 56-57). Adapun langkah-langkah pengumpulan data dalam penelitian ini adalah sebagai berikut : (a) Membaca naskah drama Bunga Rumah Makan karya Utuy Tatang Sontani; (b) Menyiapkan lembar pengumpulan data; (c) Mengumpulkan data yang berupa katakata, kalimat, paragraf dan penggalan percakapan yang sesuai dengan kajian simbolik kekuasaan Pierre Bourdieu dalam naskah drama Bunga Rumah Makan karya Utuy Tatang Sontani;

Mengklasifikasikan data tersebut ke dalam aspek modal simbolik atau kekuasaan simbolik; (e) Menyeleksi kembali setiap kelompok data yang sudah sesuai dengan rumusan; (f) Memasukkan data ke dalam tabel

\section{Teknik Analisis Data}

Teknik analisis data yang digunakan dalam penelitian ini adalah dengan menggunakan teknik deskriptif analitik yang dilakukan dengan cara mendeskripsikan fakta-fakta yang ada dalam sumber data, yang kemudian diikuti dengan tahap analisis (Ratna, 2013:53). Adapun langkah-langkah untuk menganalisis data dalam penelitian ini 
adalah sebagai berikut: (a) Melakukan analisis data dari tabel klasifikasi data yang telah dilakukan pada saat pengumpulan data; (b) Mendeskripsikan hasil klasifikasi data dalam bentuk uraian yang bersifat deskriptif. Dalam penelitian ini klasifikasi data berupa modal simbolik kekuasaan yang ditemukan dalam naskah drama Bunga Rumah Makan karya Utuy Tatang Sontani yang kemudian dideskripsikan dan dianalisis untuk menjawab rumusan masalah; (c) Menyimpulkan data hasil analisis dengan memberikan gambaran garis besar dari aspek permasalahan yang ada dalam penelitian.

\section{Hasil dan Pembahasan}

\section{Modal Simbolik Kekuasaan dalam Ranah Pekerjaan}

Kekuasaan simbolik bekerja melalui simbol-simbol bahasa untuk menggiring mereka yang didominasi untuk mengikuti makna yang diproduksi berdasarkan kepentingan mereka, yang mendominasi (Bourdieu, 1991:165). Kekuasaan simbolik sering membutuhkan simbol-simbol kekuasaan seperti jabatan, mobil mewah, kantor, prestise, gelar, status tinggi, dan keluarga ternama.

\section{Modal Simbolik Jabatan}

Modal simbolik kekuasaan dalam ranah pekerjaan terjadi di rumah makan "Sambara" tempat tokoh Ani bekerja. Dalam naskah drama Bunga Rumah Makan, modal simbolik kekuasaan yang dimiliki oleh tokoh Sudarma untuk melanggengkan kekuasaannya berupa sebuah jabatan atau profesi. Sudarma adalah pemilik rumah "Sambara". Dengan modal yang dimilikinya, Sudarma dapat melakukan tindakan atau hak untuk memerintah orang lain. Hak yang dimiliknya berkaitan dengan jabatannya sebagai pemilik rumah makan. Dengan otoritas yang dimiliknya, Sudarma dapat berkuasa dalam memerintah.

Sudarma: Eh, jika nanti Usman datang ke sini, suruh dia menyusul aku ke kantor pertemuan. Dan engkau jangan bepergian. Ani: Baik.

Sudarma: (pergi keluar).

Ani: (menyetel radio, membuka majalah melihat-lihat isinya).

Usman: (masuk). Mana tuan Sudarma, An?

Ani: (mengendurkan radio). Barusan pergi ke kantor

pertemuan, paman.

Usman: Who, katanya dia akan menunggu aku disini.

Ani: Ada juga pesannya kepada saya, supaya pamanmenyusulnya ke kantor pertemuan.

Pada data di atas kutipan dialog ke-1, modal simbolik yang digunakan adalah sebuah jabatan yang mana Sudarma merupakan pemilik rumah makan "Sambara" dan Ani sebagai pelayan rumah makan tersebut. Dalam hal ini, penggambaran bahwa tokoh Sudarma bertindak memerintah bawahnya adalah ketika Sudarma melarang Ani untuk berpergian, supaya Ani juga dapat menyampaikan pesan dari Sudarma untuk Usman.

Sudarma: Anakku sudah biasa lalai. Barusan diaketemu di jalan, tapi tidak mengatakan apaapa. (mengangkat telpon). Sembilan delapan tiga.

Ani: (mengelap kursi).

Sudarma: (kepada Ani). Meja ini masih kotor, An.

Ani: (mengelap meja).

Pada data di atas kutipan dialog ke-3 menunjukkan bahwa terdapat kekuasan yang dilakukan oleh Sudarma sebagai pemilik rumah makan yang menyuruh Ani 
untuk membersihkan meja. Modal simbolik jabatan digunakan oleh Sudarma untuk melanggengkan hak dan wewenangnya.

\section{Modal Simbolik Prestise atau Citra}

Modal simbolik menurut Bourdiue dapat berupa prestise atau berbentuk citra. Citra dalam hal ini adalah sebagai hal yang dapat ditukar dengan keuntungan dalam aspek ekonomi. Modal simbolik dalam bentuk prestise yang muncul, dapat berupa barang atau sesuatu hal yang dapat dijadikan sebagai nilai yang mampu menaikkan keuntungan pada seseorang.

Ani: Tetapi itu bukan lantaran saya tidak kawin, paman.Orang itu tidak sopan saja, boleh jadi setengah matang.

Usman: Kalau engkau punya suami, kan tidak akan ada lagi laki-laki yang mau mengganggu engkau.

Sudarma: (menghitung uang di atas meja tulis). Tapi kalaudia sudah kawin, berarti akan meninggalkan pekerjaan disini. Itu tak hendak kuijinkan.

Modal simbolik yang digunakan oleh tokoh Sudarma pada dialog di atas yaitu prestise, ketika tokoh Usman menyarankan kepada tokoh Ani untuk menikah supaya tidak diganggu oleh laki-laki yang datang di rumah makan "Sambara", namun Sudarma sebagai pemilik rumah makan tersebut tidak mengizinkan hal itu dikarenakan jika tokoh Ani menikah tentunya ia akan meninggalkan pekerjaannya sebagai pelayan, maka akan membuat rumah makan tersebut tidak ramai lagi, karena tokoh Ani merupakan primadona dari rumah makan tersebut.

Sudarma: Kok lupa! Kan tadi aku sudah berpesan supaya yang menanyakan aku, mesti kau catat dan tanya apa keperluannya. Jika begitu, sia-sia saja aku menggaji orang disini.
Ani: (menundukkan kepala)

Sudarma: Itu berarti melalaikan keuntungan. Sebab orang yang menelpon itu sudah pasti berurusan dagang.

Pada data di atas kutipan dialog ke-3, modal simbolik yang digunakan adalah prestise atau citra. Dalam hal ini pestise atau citra tersebut berupa kegiatan ekonomi.

\section{Modal Simbolik Kekuasaan dalam Ranah Masyarakat}

Perbedaan status sosial dalam masyarakat membuat seseorang dengan mudah untuk mendominasi yang dibawahnya, perbedaan antara si kaya dengan si miskin yang ditampilkan dalam naskah drama Bunga Rumah Makan. Sehingga, modal simbolik dalam ranah masyarakat menggiring mereka yang didominasi untuk mengikuti makna yang diproduksi berdasarkan kepentingan mereka, yang mendominasi.

Sudarma: (masuk menjinjing tas, melihat kepada pengemis). Mengapa kau ada di sini? Ayo keluar!(kepada Ani). Mengapa dia dibiarkan masuk, An?

Ani: Hendak saya beri uang.

Sudarma: Tak perlu. Pemalas biar mati kelaparan. Toh dia datang hanya mengotorkan tempat saja.

Pada data di atas kutipan dialog ke-1, Sudarma tidak berkenan mengizinkan ada pengemis yang masuk ke rumah makannya. Modal simbolik yang terlihat adalah status sosial yang melekat pada Sudarma yang merupakan pemilik rumah, dan si pengemis hanya datang dan meminta untuk diberi makan atau uang.

Karnaen : Engkau di sini rupanya mencari perselisihan ya? Kalau begitu, atas nama ketertiban rumah makan ini, engkau kuusir, mesti pergi sekarang juga. Jika tidak, nanti kupanggil polisi. 
Iskandar: Panggilah polisi, supaya kian jelas, bahwa orang-orang disini dibelenggu, menggantungkan diri kepada orang lain.

Pada data di atas kutipan dialog ke-1 menunjukkan bahwa terdapat modal simbolik dalam ranah masyarakat yang menggunakan status sosialnya sebagai salah satu cara untuk melanggengkan kekuasaan. Karnaen merupakan anak dari Sudarma pemilik rumah makan sedangkan Iskandar adalah pemuda pelancongan yang saat itu hendak bersinggah di rumah makan tersebut, karena telah membuat keributan sehingga Karnaen memiliki hak dan wewenang dengan mudah menyuruh Iskandar untuk pergi dari rumah makannya.

Ani: Sudah, tapi dia tak mau pergi.

Karnaen: (kepada Iskandar). Saya minta dengan sangat, supaya saudara pergi meninggalkan tempat ini.

Iskandar: Perlu apa saudara turut campur?

Karnaen: Saya orang disini.

Pada data di atas kutipan dialog ke-4 modal simbolik kekuasaan yang digunakan adalah status sosial. Dimana status sosial antara Karnaen dan Iskandar sangat berbeda. Karnaen memiliki status sosial yang tinggi dan sudah diketahui oleh masyarakat, sehingga memudahkan Karnaen untuk melakukan hak dan wewenangnya.

Usman: Apa salahnya setelah kawin dia tetap bekerja disini? Dengan begitu malah memberi kesucian kepada rumah makan ini, sebab nanti tidak akan ada lagi lakilaki yang datang disini dengan maksud hanya main-main dengan Ani. Betul tidak, An?

Ani: Betul juga, paman.
Usman: Nah, kawinlah! Jangan jauh mencari suami, kawinlah dengan Karnaen. Karnaen: Tidak, paman. Dia sudah ada mempunyai pemuda yang diidamidamkannya.

Pada data di atas kutipan dialog ke-3, Usman merupakan seorang kyai, Ia menyuruh Ani untuk segera menikah supaya tidak ada laki-laki yang mengganggunya. Kedudukan Usman di masyarakat sebagai Kyai termasuk dalam jenis modal simbolik. Dengan modal simbolik yang dimiliknya Usman dapat menyuruh Ani untuk segera menikah.

\section{Simpulan}

Berdasarkan dari hasil analisis dan pembahasan dalam Naskah drama Bunga Rumah Makan karya Utuy Tatang Sontani dengan kajian Pieree Bourdiue yang lebih memfokuskan pada modal simbolik kekuasaan, dapat disimpulkan bahwa modal simbolik kekuasaan yang ditemukan dalam naskah drama tersebut adalah (1) modal simbolik dalam ranah pekerjaan dengan simbol jabatan dan prestise atau citra. Modal simbolik dalam bentuk jabatan lebih sering digunakan oleh tokoh Sudarma sebagai pemilik rumah makan yang tentunya memiliki wewenang dan hak untuk memerintah. Sedangkan, modal simbolik dalam bentuk prestise atau citra juga digunakan oleh tokoh Sudarma untuk melanggengkan kekuasaannya. Prestise atau citra dalam hal ini berupa sesuatu yang dapat menghasilkan keuntungan atau ekonomi; (2) modal simbolik dalam ranah masyarakat yang ditemukan hanya status sosial, status sosial dalam masyarakat juga merupakan modal simbolik. Dalam naskah drama Bunga Rumah Makan status sosial digunakan oleh tokoh Sudarma, Karnaen, dan Usman untuk melanggengkan kekuasaannya. 


\section{Daftar Pustaka}

Bourdieu, Pierre. 1991. Language and Symbolic Power. Cambridge: Polity Press.

Bourdieu, Pierre. 2001. Masculine Domination. Stanford Calif: Stanford University Press.

Bourdieu, Pierre. 2010. Arena Produksi Kultural. Diterjemahkan oleh Yudi Santsa.Yogyakarta: Kreasi Wacana.

Endraswara, Suwardi. 2011. Metode Pembelajaran Drama. Yogyakarta: CAPS.

Faruk. 2012. Metode Penelitian Sastra. Indonesia: Rosda.

Fananie, Zainuddin. 2000. Telaah Sastra. Surakarta: Muhammadiyah University Press.

Fashri, Fauzi. 2014. Pierre Bourdieu Menyingkap Kuasa Simbol. Yogyakarta: Jalasutra

Ginting, H. S. P. H. (2019). Novel Sang Pemimpi karya Andrea Hirata: Analisis.

Habitus dan Modal dalam Arena Pendidikan Menurut Perspektif Pierre Bourdieu. Sintesis, 13(1), 47-56.

Haryatmoko. 2003. Menyingkap Kepalsuan Budaya Penguasa. Dalam Majalah Basis, No. 11-12, NovemberDesember 2003, hlm. 5-23.

Karnanta, Kukuh Yuda. 2013. Paradigma Teori Arena Produksi Kultural sastra:
Kajian Terhadap Pemikiran Pierre Bourdieu. Jurnal Poetika: Jurnal Ilmu Sastra, 1(1), 3-15.

Martono, Nanang. 2012. Kekerasan Simbolik di Sekolah. Jakarta: PT RajagrafindoPersada.

Novenia, M., Taum, Y. Y., \& Adji, S. E. P. (2019). Strategi Dominasi dalam Novel Maryam Karya Okky Madasari: Perspektif Pierre Bourdieu. Sintesis, 13(2),102-111.

Nursandi, S. N., Juanda, J., \& Hajrah, H. (2020). Kekerasan Simbolik Dalam NovelSophismata Karya Alanda Kariza (Perspektif Sosiologi Pierre Bourdieu) (Doctoral Dissertation, Universitas Negeri Makassar).

Syahril. 2014. Arena Produksi Kultural Dan Kekerasan Simbolik (AnalisisTerhadap Novel Banât AlRiyâdh Perspektif Sosiologi Pierre Bourdieu). Jurnal Ilmiah Peuradeun: Media Kajian Ilmiah Sosial, politik, hukum, agama dan Budaya, 2(1), 7592.

Swingewood, Alan and Diana Laurenson. 1972. The Sociology of Literature. Paladine.

Ratna, Nyoman Kutha. 2004. Teori, Metode, dan Teknik Penelitian Sastra. Yogykarta: Pustaka Pelajar.

Rusyana, Yus. 1987. Payungsi Sastra. Bandung: Rahmat Cijulang. 
BIP: Jurnal Bahasa Indonesia Prima Vol. 3, No. 2, 2021, September 2021, PP.

Waluyo, Herman. J. 2003. Drama: Teori dan Pengajarannya. Yogyakarta : Hanindita Graha Widya.

Widodo, B. W., \& Adji, S. E. P. (2019). Dominasi Maskulin dalam Novel Dua Ibu Karya Arswendo Atmowiloto: Perspektif Pierre Bourdieu. Sintesis, 13(2), 93-101. 